\title{
Report from the President
}

\author{
By Barbara J. Ford
}

President, ACRL

\section{Underrepresented minorities}

At the 1990 Annual Conference in Chicago the ACRL Board of Directors received the final report of the ACRL Task Force on Recruitment of Underrepresented Minorities. This Task Force was established by ACRL President Joseph Boissé and ably chaired by Edith Maureen Fisher from the University of California, San Diego. The report will be reviewed at the fall meeting of the ACRL Executive Committee and appear in the December issue of $C \mho R L$ News. As we prepare to act on the important recommendations in the report, I wanted to review the ALA Policy Manual for relevant ALA policies.

Under ALA priority Area E (Personnel Resources), Goal 8 states that "Librarianship recruits a racially and ethnically diverse group of high caliber persons." Under Priority Area F (Library Services, Development, and Technology), Goal 11 states that "Libraries are proactive agencies which meet the challenges of social, economic, and environmental change."

ALA has an official Policy on Minority Concerns (Policy 59). It states:

"The American Library Association promotes equal access to information for all persons and recognizes the urgent need to respond to the increasing racial and ethnic diversity among Americans. African-Americans, Hispanic Americans, Asian American, Native Americans, and other minorities have critical and increasing needs for information and library access. They are affected by a combination of limitations including illiteracy, language barriers, economic distress, cultural isolation, and discrimination in education, employment, and housing. Therefore, the role played by libraries to enable minorities to participate fully in a democratic society is crucial. Libraries must utilize multivariate resources and strategies to empower minority people. Concrete programs of recruitment, training, development, and upward mobility are needed in order to increase and retain minority personnel within librarianship. Within the American Library Association, the coordinating mechanisms for programs and activities dealing with minorities in various ALA divisions, offices, and units should be strengthened, and support for minority liaison activities should be enhanced."

Policy objectives include:

"1. Promoting the removal of all barriers to library and information services, particularly fee charges and languages barriers.

" 2 . Promoting the publication, production, and purchase of print and nonprint materials that present positive role models of cultural minorities.

“3. Promoting full funding for existing legislative programs in support of minority education and training, and to explore alternative funding sources for scholarships, fellowships, and assistantships to encourage minority recruitment into librarianship.

"4. Promoting training opportunities for librarians, including minorities, in order to teach effective techniques for generating tripartite public funding for upgrading library services to minorities.

“5. Promoting the incorporation of minority programs and services into the regular library budgets in all types of libraries, rather than the tendency to support these activities solely from 'soft monies' such as private grants or federal monies.

"6. Promoting equity in funding adequate library services for minority populations, in terms of professional and nonprofessional personnel, materials, resources, facilities, and equipment.

“7. Promoting supplemental support for library resources on cultural minorities by urging local, state, and federal government, and the private sector, to provide adequate funding.

"8. Promoting increased public awareness of the importance of library resources and services in all segments of society, especially minority communities. 
“9. Promoting the determination of output measures through the encouragement of community needs assessments, giving special emphasis to assessing the needs of cultural minorities.

"10. Promoting increased staff development opportunities and upward mobility for minority librarians."

Combating Prejudice, Stereotyping, and Discrimination (Policy 59.2): "The American Library Association actively commits its prestige and resources to a coordinated action program that will combat prejudice, stereotyping, and discrimination against individuals and groups in the library profession and in library service because of race, sex, creed, color, or national origin."

Goals for Indian Library and Information Services (Policy 59.3):

"1. All library and information services must show sensitivity to cultural and social components existent in individual Indian communities.

" 2 . Indian representation through appointment to local boards and creation of local advisory committees concerning services to and about American Indians are essential for healthy, viable programs.

“3. Materials which meet information and educational needs and which present a bicultural view of history and culture must be provided in appropriate formats, quality, and quantity to meet current and future needs.

“4. Library programs, outreach and delivery systems must be created which will insure rapid access to information in a manner compatible with the community's cultural milieu.

"5. American Indian personnel trained for positions of responsibility are essential to the success of any program.

"6. Continuing funding sources for library and information services must be developed."

Library Education to Meet the Needs of SpanishSpeaking People (Policy 59.4):

"The American Library Association will take steps through its Committee on Accreditation to encourage graduate library schools seeking accreditation or reaccreditation to assure that course content reflects the cultural heritage and needs of the Spanish-speaking people of the United States and will encourage such schools to include bilingual/bicultural persons on their faculties."

\section{Latinos in State Agencies (Policy 59.5):}

"The American Library Association urges and supports the recruiting, hiring, and promotion of Latinos within the state library structure, especially in the areas of administration and consultation."

\section{Visiting Fellowships at Beinecke Rare Book \& Manuscript Library}

The Beinecke Rare Book and Manuscript Library offers short-term fellowships for visiting scholars pursuing post-doctoral or equivalent research in its collections. The fellowships, which support travel to and from New Haven and pay a living allowance of $\$ 1,500$ per month, are designed to provide access to the library for scholars who reside outside the greater New Haven area. The length of a grant, normally one month, will depend on the applicant's research proposal; fellowships are between September 1991 and May 1992. Recipients are expected to be in residence during the period of the award.

The proposal should emphasize the relationship of the Beinecke collections to the project and state the preferred dates of residence. The applicant must also arrange to have two confidential letters of recommendation sent to the director. The following named fellowships will be among those awarded: The Frederick $W$. Beinecke Fellowship in Western Americana, The H.D. Fellowship in English or American literature, The Donald C. Gallup Fellowship in American literature, The A. Bartlett Giamatti Fellowship, The H.P. Kraus Fellowship in early books and manuscripts, The Alexander O. Vietor Fellowship in cartography and related fields. All application materials must be received by January 15, 1991. Awards will be announced in March 1991 for the period September 1991 through May 1992.

There is no special application form. Applicants are asked to submit a resume and a brief research proposal (not to exceed three pages) to: Director, Beinecke Rare Book \& Manuscript Library, Box 1603A Yale Station, New Haven, CT 06520-1603.

The proposal should emphasize the relationship of the Beinecke collections to the project and state the preferred dates of residence. The applicant must also arrange to have two confidential letters of recommendation sent to the Director.

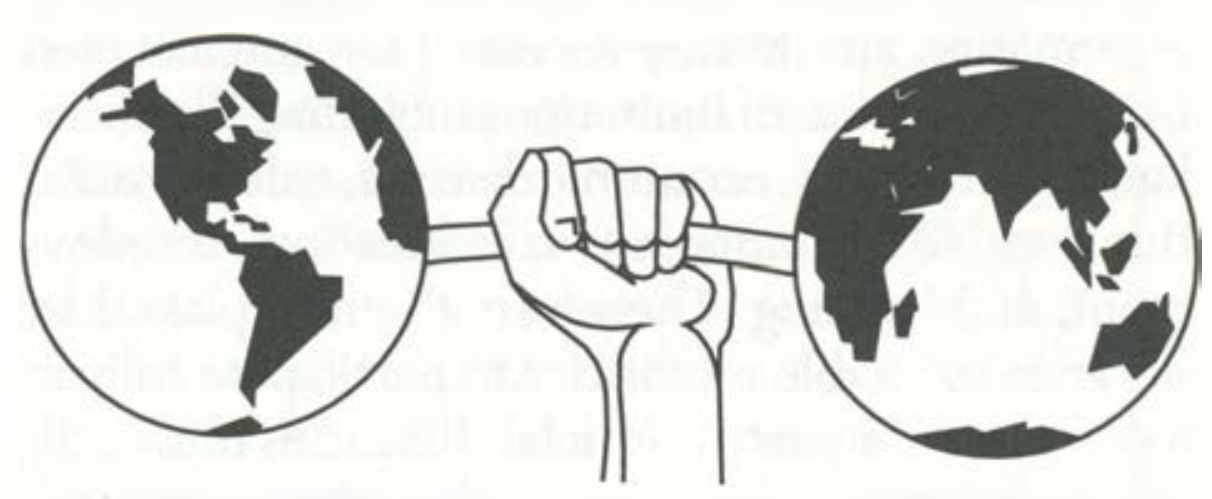




\section{Introducing... \\ ENVIRO/ENERCYLINE Abatracts Plus ${ }^{\mathrm{rm}}$ \\ and \\ SUPERTECH \\ Abetracts Plus' \\ CD-ROM research and delivery systems focusing on today's most crucial areas of scientific endeavor.}

Wlave mobile robots mastered visual natiotion?

Will dagan oulpate the U.S.

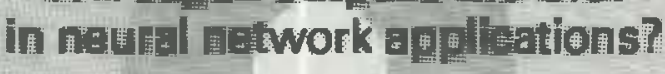

Where eari I find the latest patents on computer Fralghics?

\section{BUPERTECH}

Abetreate Plus
Fin: is recycled?

What papers were delivered at ASME's International

Solar Energy Conference?

Whicfirstates have enacted legislation to fight acid rain?

\section{\#NVIR:} Abetracte Plus
Versatile, One-Stop Access to All the Literature You Have and Don't Have-on topics from global warming to geometric modelling!

\section{ENVIRO/}

\section{ENERGYLINE} Abstracte Plus ${ }^{\text {TM }}$ Features the entire backfile and all current abstracts and citations from

Environment Abstracts, Acid Rain Abstracts, and Energy Information

Abstracts-more than

200,000 records from 1970 to the present with 3,000 new records added every three months.

\section{BUPERTECH}

\section{Abetracte Plus ${ }^{\mathrm{TM}}$}

Three databases consolidated into one high-tech "superbase," SUPERTECH Abstracts Plus cumulates all current and past citations and abstracts from CAD/CAM Abstracts, Artificial Intelligence Abstracts, and Robotics Abstracts-more than 35,000 records, from 1983 to the present, with over 2,000 new records added every three months.

\section{THERE ARE SIMPLE ANSWERS TO ANY OF YOUR QUESTIONSI}

\section{ENVIRO/ENEREYLINE Abstracts Plus on EupEaTEch Abetracte Plue}

For years Bowker A \& I Publishing has been collecting, classifying, and digesting over 10,000 technical and non-technical sources in the environmental and high-tech fields. Now we've converted our A \& I databases into flexible CD-ROM format-and produced a viable solution to the problem of rising serials prices and publishing activity. For the price of a few professional journals, you'll extend your coverage and enjoy unrestricted CD-ROM access to an international clearinghouse of scientific, public policy, economic, legal, and consumer-oriented research.

A \& I's information-packed databases and the powerful retrieval software similar to other of Bowker's Plus System ${ }^{\text {Tw }}$ CD-ROM products, will not only speed up the research process, but also improve the quality and content of your results with...

- On-site, immediate 24hour access to the resources normally dispersed among hundreds of specialized collections.

- On Hand or On Demand exploration of documents at their source through companion microfiche collections or ordering directly through your computer-or by phone or fax.

- Fielded and full-text searching by custom searching each CD-ROM by combining 16 traditional points of entry, such as title, subject, author, date, document type, and more.

- Cumulative, quarterly updates to keep you current on the latest trends, issues, and advances.

\section{Call us today TOLL-FREE 1-800-323-3288 for details.}

Bowker Electronic Publishing - 121 Chanlon Road - Now Providence, NJ 07974 